\title{
Resilient Backpropagation Neural Network on Prediction of Poverty Levels in South Sulawesi
}

\author{
Bobby Poerwanto, Fajriani
}

Universitas Muslim Indonesia, Indonesia

\begin{tabular}{|c|c|}
\hline Article Info & ABSTRACT \\
\hline Article history: & Poverty is a topic that continues and is always discussed up to this time, as a \\
\hline Received, 25 April 2020 & benchmark indicator of how the level of welfare and prosperity in the lives of \\
\hline Revised, 14 May 2020 & $\begin{array}{l}\text { people in a country. Several attempts have been made by the central and } \\
\text { regional governments to reduce poverty levels, including "Bantuan Langsung }\end{array}$ \\
\hline Accepted, 28 August 2020 & Tunai" (BLT) and the "Program Keluarga Harapan" (PKH). However, poverty \\
\hline Keywords: & $\begin{array}{l}\text { Based on this, this study aims to predict poverty levels in South Sulawesi. } \\
\text { Factors thought to influence poverty levels are the Human Development Index }\end{array}$ \\
\hline Accuracy & (HDI), the Open Unemployment Rate (TPT), and the Gross Regional \\
\hline Resilient Algorithm & Domestic Product (GRDP). The data used are data from 2010 to 2014. The \\
\hline Backpropagation Neural Network & method used is a backpropagation neural network with a resilient algorithm or \\
\hline Proverty Levels & better known as a resilient backpropagation neural network (RBNN). The \\
\hline Prediction & $\begin{array}{l}\text { results of the prediction of poverty levels using predictors of HDI, TPT, and } \\
\text { GRDP showed that the analysis of the RBNN reached its optimum using } \\
\text { architecture }[3-9-1] \text { and reached convergence at the } 81^{\text {th }} \text { iteration with an } \\
\text { accuracy rate of } 95.34 \% \text {. }\end{array}$ \\
\hline
\end{tabular}

This is an open access article under the CC BY-SA license.

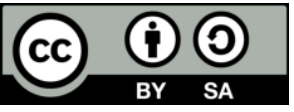

\section{Corresponding Author:}

Bobby Poerwanto,

Department of Computer Science,

Universitas Muslim Indonesia.

Email: bobbybp89@gmail.com

\section{INTRODUCTION}

Poverty is one indicator that must be considered by the government. This is because poverty is an important aspect in measuring the level of community welfare. Several attempts were made by the central or regional government to reduce poverty, asking for "Bantuan Langsung Tunai" (BLT) and the "Program Keluarga Harapan" (PKH). However, poverty reduction in Indonesia is still slowing down. It is known that the number of poor people in Indonesia in March 2019 reached 25.14 million people. Compared to September 2018 , the number of poor people increased by 529.9 thousand people. However, at the end of 2019 it was still $9.41 \%$ [1]. The number of poor people in South Sulawesi in the last 5 years is still above 500 thousand people. Compared to previous years, the number of poor people has decreased, but not significant, as in 2017 the poverty rate in South Sulawesi reached $9.38 \%$ and the following year $9.06 \%$, meaning that in one year it only fell by $0.32 \%$. The accumulation of poverty levels in South Sulawesi in the last five years only decreased by $0.48 \%$ [2], []].

Poverty in recent years has become one of the important topics in research. As research on the analysis of factors that affect poverty in Indonesia for 5 years. The analysis shows that the HDI and the unemployment rate affect changes in poverty levels in 33 provinces in Indonesia [4]. Then research on how much influence from inflation, education, income, household consumption, and the Human Development Index (HDI) affect poverty levels in Indonesia. The result is that poverty levels in Indonesia are influenced by large household consumption and HDI [5]. Both of these studies use multiple linear regression analysis. Clustering analysis has also been used to analyze poverty data. Such as poverty data research in Yogyakarta. The research uses Fuzzy $\mathrm{C}$-means algorithm and K-means algorithm. The results of the analysis show that by using 15 indicators that affect poverty levels, the K-means algorithm gives better results than Fuzzy C-means []․ Other studies apply 
backpropagation neural networks (BNN) to predict poverty levels. The results of the analysis show that the prediction model with BNN gives better results than other mathematical models [7]. Next is the analysis of poverty levels using generalized regression neural networks (GRNN) []․ The response of the two studies above is the metric data.

Based on the description above, this study will predict poverty levels with predictors of the human development index (HDI), the level of open unemployment (TPT) [4] , and add one new variable, namely gross regional domestic product (GRDP). The method used is based on research conducted by Mulyani [7], namely using BNN. The difference is this research uses responses in the form of nonmetric data (categorical) and the algorithm used is the resilient algorithm.

Neural network $(\mathrm{NN})$ is one of the analytical techniques that can be used in various disciplines [ $\underline{9}$ ]. This method is one part of Artificial Intelligence (AI) which is formed based on the human nervous system. Various types of NN are able to show their potential in solving problems [10]. One indicator in NN is the level of accuracy. One method in NN that can produce optimum accuracy is backpropagation [11]. The disadvantage of backpropagation neural networks (BNN) is the achievement of slow convergence. One that can be used to overcome these problems is to use a resilient algorithm [11]. This method is often known as resilient backpropagation neural network (RBNN). This RBNN is able to provide faster convergence than BNN methods in the training data used in simulations. This resilient algorithm is first used in single dimension and two dimensional data. But now it can be developed into multidimensional [12].

The RBNN has been applied in various fields. For example, research on estimating waiting times in queues at a bank [13]. The analysis shows that the RBNN provides a better estimate of waiting time than using time series analysis. The second study is about optimizing accuracy in predicting financial distress in 2017 [14]. Based on this research the optimum accuracy is $90.48 \%$. The results of the accuracy with the RBNN were $23.81 \%$ higher than using the logistic regression model. Next is the application of RBNN in anoxic biotrickling filters to remove hydrogensulfide from artificial biogas [15]. The results obtained are NN with a resilient algorithm capable of eliminating $\mathrm{H}_{2} \mathrm{~S}$ in biogas quickly without damaging biogas levels. The next RBNN is used in the validation of macroscopic traffic flow models compared to the automatic differentiation software (ADOL-C) method. The research shows that the RBNN provides more accurate and optimum model results in the settlement of traffic flow cases [16]. The results of the RBNN in some of these studies have shown that the resilient algorithm performance at BNN gives better results than other algorithms, both using metric, nonmetric, and data series data.

In this study will use nonmetric data from poverty level data. Where the poverty level data will be categorized into 2 , namely the first category is the low poverty rate $(<$ average of South Sulawesi) and the second category is the high poverty rate $(\geq$ average of South Sulawesi.

\section{RESEARCH METHOD}

The data used in this study are secondary data obtained from the South Sulawesi BPS which consists of poverty level data as a response, and HDI, TPT, GRDP as predictors recorded in 2010 to 2014. The data are 120 , consisting of 24 districts / city recorded for 5 years. The response used is nonmetric data, so the poverty level is converted into 2 categories. the first category with index 0 , which is a low poverty rate $(<$ South Sulawesi average). the second category is index 1 , which is a high poverty rate ( $\geq$ South Sulawesi average). RBNN is an efficient machine learning method in producing a prediction. The RBNN architecture in figure 1.

The difference in the use of resilient algorithms in BNN with other algorithms is the update of new values on each weight to determine new weights, as shown in Figure 1. Changes in the adaptive value take place during the algorithm process in the training data run in accordance with the learning rule as equation (1).

$$
\Delta_{i j}^{(t)}= \begin{cases}\eta^{+} \times \Delta_{i j}^{(t-1)}, j i k a & \frac{\partial F^{(t-1)}}{\partial w_{i j}} \times \frac{\partial F^{(t)}}{\partial w_{i j}}>0 \\ \eta^{-} \times \Delta_{i j}^{(t-1)}, \text { jika } & \frac{\partial F^{(t-1)}}{\partial w_{i j}} \times \frac{\partial F^{(t)}}{\partial w_{i j}}<0 \\ \Delta_{i j}^{(t-1)} & \text { untuk yanglain }\end{cases}
$$




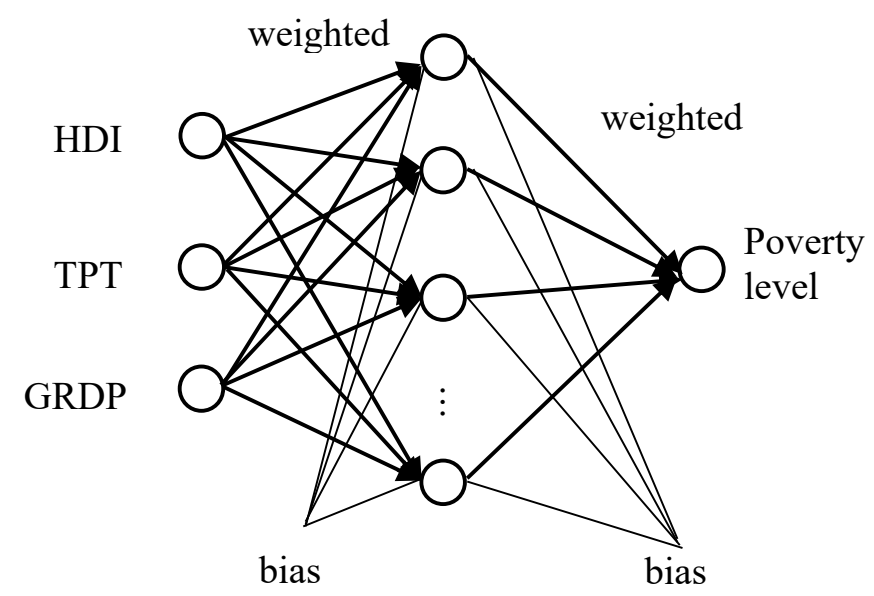
Input
Hidden
Output
Layer
Layer
Layer

Figure 1. RBNN Architecture on Research

Where $0<\eta^{-}<1<\eta^{+}[\underline{11}]$.

In other words, this adaptive function functions as follows: 1) if $\partial F$ against $w_{i j}$ changes the sign, then $\Delta_{i j}$ is reduced by the $\left.\eta^{-} ; 2\right)$ if the partial derivative does not change the sign, then $\Delta_{i j}$ increases. After $\Delta_{i j}$ for each weight is adjusted, weight updates also follow very simple rules, as shown in the equation (2).

$$
\Delta w_{i j}^{(t)}=\left\{\begin{array}{lll}
-\Delta_{i j}^{(t)}, & j i k a & \frac{\partial F^{(t)}}{\partial w_{i j}}>0 \\
+\Delta_{i j}^{(t-1)}, & j i k a & \frac{\partial F^{(t)}}{\partial w_{i j}}<0 \\
\Delta_{i j}^{(t-1)} & & \text { untuk yang lain }
\end{array}\right.
$$

$w_{i j}^{(t+1)}=w_{i j}^{(t)}+\Delta w_{i j}^{(t)}$

However, if the partial derivative results change marks, for example the results in the previous stage are too large, then the weight change is:

$$
\Delta w_{i j}^{(t)}=-\Delta w_{i j}^{(t-1)}, j i k a \frac{\partial F^{(t-1)}}{\partial w_{i j}} \times \frac{\partial F^{(t)}}{\partial w_{i j}}<0
$$

The algorithm in the RBNN is as follows:

For all weights and biases in the hidden layer used [11]. 


$$
\begin{aligned}
& \text { if }\left(\frac{\partial F^{(t-1)}}{\partial w_{i j}} \times \frac{\partial F^{(t)}}{\partial w_{i j}}>0\right) \text { then }\{ \\
& \Delta_{i j}^{(t)}=\min \left(\eta^{+} \times \Delta_{i j}^{(t-1)}, \Delta_{\max }\right) \\
& \Delta w_{i j}^{(t)}=-\operatorname{sign}\left(\frac{\partial F^{(t)}}{\partial w_{i j}}\right) * \Delta_{i j}^{(t)} \\
& w_{i j}^{(t+1)}=w_{i j}^{(t)}+\Delta w_{i j}^{(t)} \\
& \} \\
& \text { else if }\left(\frac{\partial F^{(t-1)}}{\partial w_{i j}} \times \frac{\partial F^{(t)}}{\partial w_{i j}}<0\right) \text { then }\{ \\
& \Delta_{i j}^{(t)}=\max \left(\eta^{-} \times \Delta_{i j}^{(t-1)}, \Delta_{\min }\right) \\
& w_{i j}^{(t+1)}=w_{i j}^{t}-\Delta w_{i j}^{(t-1)} \\
& \frac{\partial F^{(t)}}{\partial w_{i j}}=0 \\
& \} \\
& e l s e i f\left(\frac{\partial F^{(t-1)}}{\partial w_{i j}} \times \frac{\partial F^{(t)}}{\partial w_{i j}}=0\right) \text { then }\{ \\
& \Delta_{i j}^{(t)}=\Delta_{i j}^{(t-1)} \\
& \Delta w_{i j}^{(t)}=-\operatorname{sign}\left(\frac{\partial F^{(t)}}{\partial w_{i j}}\right) * \Delta_{i j}^{(t)} \\
& w_{i j}^{(t+1)}=w_{i j}^{(t)}+\Delta w_{i j}^{(t)} \\
& \}
\end{aligned}
$$

The results of the RBNN for predicting poverty levels also see the level of accuracy obtained. This accuracy is obtained by formula:

$$
\begin{aligned}
& \text { Sensitivity }=\frac{T P}{T P+F N} \\
& \text { Spesificity }=\frac{T N}{T N+F P} \\
& \text { Accuracy }=\frac{T P+T N}{T P+T N+F P+F N}
\end{aligned}
$$

The analysis phase in this research is as follows:

1. Converting proverty level data into categories 0 and 1 with the provisions of 0 for the proverty rate $<$ South Sulawesi average and 1 for the proverty level $\geq$ South Sulawesi average.

2. The division of data into 5 folds.

3. The division of fold into 2 groups, namely fold for training data and fold for testing data with a ratio of 3 : 2 .

4. The preparation of the algorithm starts from determining the initial weight to the last output as an estimate of the dependent variable.

5. Making a program using R software.

6. Poverty level prediction is based on predictors of HDI, TPT, and GRDP.

7. Calculate the accuracy of the predicted results.

\section{RESULTS AND ANALYSIS}

The first step in conducting an analysis with the RBNN is to divide the data into 5 folds with each fold consisting of 24 districts / cities. The 5 folds are divided into 2 parts, with 3 folds for training data (data from 2010 to 2012) and the next 2 folds for testing data (data for 2013 - 2014). After the data is divided into two 
parts, namely training and testing data, the next step is to analyze the training data to form a model. Then validate the results obtained from the training data using testing data. After the results are formed, then determine the level of accuracy.

The analysis in the RBNN in this study uses the log-sigmoid activation function, because the expected output is in the form of categories 0 and 1 . The hidden layer used only consists of 1 layer and the hidden layer is simulated with several different nodes, including $1,3,5,7$, and 9. The results of the RBNN analysis for the prediction of poverty levels are in table 1 .

Table 1. Predicted Results with RBNN

\begin{tabular}{cccc}
\hline \multicolumn{4}{c}{ Training Data } \\
\hline \multirow{2}{*}{ Predictors } & $\begin{array}{l}\text { The RBNN } \\
\text { Arsitecture }\end{array}$ & Iteration & Accuracy \\
\hline & {$[3-1-1]$} & 133 & $45,21 \%$ \\
HDI, TPT, & {$[3-3-1]$} & 117 & $48,12 \%$ \\
GRDP & {$[3-5-1]$} & 127 & $52,11 \%$ \\
& {$[3-7-1]$} & 114 & $59,27 \%$ \\
& {$[3-9-1]$} & 106 & $60,30 \%$ \\
\hline HDI, TPT, & {$[3-1-1]$} & 112 & $68,97 \%$ \\
GRDP & {$[3-5-1]$} & 103 & $74,88 \%$ \\
& {$[3-7-1]$} & 111 & $82,91 \%$ \\
& {$[3-9-1]$} & 97 & $91,11 \%$ \\
\hline
\end{tabular}

The results in table 1 above show that the prediction of poverty levels with 3 factors (HDI, TPT, GRDP) is optimum in architecture [3-9-1] both in training and testing data. The architecture is in a hidden layer using 9 nodes and converges to the 106th iteration for training data and the 81st iteration for testing data. Determination of the optimum prediction results is based on the level of accuracy obtained. Based on table 1 it is known that the highest accuracy of the training data is $60.30 \%$. The analysis using training data aims to determine the prediction model for poverty levels using the RBNN. Furthermore, the model formed is validated using testing data.

The results of the analysis in table 1 show that there is a consistency of results between training data and testing data. The results of the prediction of poverty levels using the RBNN show that the more nodes used in the hidden layer, the faster the convergence and accuracy will increase. This can be seen in the results of the iteration obtained. Prediction of testing data by using 9 nodes produces the highest accuracy value and achieves faster convergence. The resulting accuracy is $95.34 \%$ and reaches convergence with an iteration of 81 times.

This study obtained results in line with previous studies, getting optimum results with a faster convergent process. As research on the prediction of financial distress companies. The results obtained are optimum predictions with an accuracy level of $90.48 \%$ and reach convergence at 4,536 iterations. The iteration in other RBNN architectures is $>5,000$ times [14]. This study obtained results that are in line with this RBNN research which is also more effective than other NN methods, such as research on heat transfer. The analysis shows that the RBNN is more effective and efficient in predicting the results of heat transfer [10]. Other research also shows the same thing, namely that the RBNN is faster at achieving convergence and optimum results in highdimensional data analysis [17].

In contrast to previous research, conducted by Mulyani [7], in this study using nonmetric data. So the output produced is also different. In the previous research, it was in the form of metric data, namely the percentage of poverty level, whereas in this study it was in the form of nonmetric data with categories 0 and 1 . The iteration of the prediction of poverty level in this study was also better. The optimum results for prediction using training data in this study occurred in the $106^{\text {th }}$ iteration, while the research conducted by Mulyani [7] optimum at 5,000 iterations.

The application of the RBNN for the prediction of poverty levels gets better results when compared to the prediction of financial distress companies [14]. In terms of accuracy, the application of the RBNN for predicting poverty rates results in higher accuracy than the prediction of financial distress companies, which is $95.34 \%$ for predictions of poverty levels and the prediction of financial distress for companies is only $90.48 \%$. In terms of convergence, poverty rate predictions are also faster when compared to financial distress predictions. It was noted that the prediction of poverty level reached optimum and convergent in the $81 \mathrm{st}$ iteration, while the prediction of financial distress was 4,536 [14]. This difference is caused because the number of data samples used and the number of inputs used are different. In the prediction of financial distress, the number of sample data and inputs used is doubled. 
Based on the description above, it can be said that the RBNN is one of the NN methods that can produce predictions with efficient and better results than other NN methods. The RBNN is faster at converging in predictions and can produce high accuracy as well. In addition, the RBNN can be used in research with highdimensional data. This RBNN is not only used for metric data or data series, but can also be used for nonmetric (categorical).

\section{CONCLUSION}

From the results of the analysis show that the prediction of poverty levels using HDI, TPT, and PDRB predictors converges at the 81 st iteration and an accuracy rate of $95.34 \%$. The use of architecture [3 - $9-1]$ has given the most optimum results than the use of other architectures. The results above still need further research by comparing the use of different architectures, namely only 1 input ( 1 predictor) and 2 inputs ( 2 predictors). So that later can be compared with the results using 3 inputs ( 3 predictors). This RBNN can be used in various disciplines. So that in the future it can be turned into other fields, such as education and health.

\section{ACKNOWLEDGEMENTS}

The researcher would like to thank Universitas Cokroaminoto Palopo for giving permission to collaborate in the field of research and for providing moral and material support through an external research grant based on beginner lecturers to their lecturers, so that this research can be carried out well.

\section{REFERENCES}

[1] Badan Pusat Statistik, Profil Kemiskinan di Indonesia Maret 2019. Jakarta: Badan Pusat Statistik, 2019.

[2] Badan Pusat Statistik, Profil Kemiskinan di Indonesia September 2018. Jakarta: Badan Pusat Statistik, 2019.

[3] Badan Pusat Statistik Provinsi Sulawesi Selatan, Profil Kemiskinan Sulawesi Selatan, September 2018. Makassar: Badan Pusat Statistik Provinsi Sulawesi Selatan, 2019.

[4] N. Zuhdiyaty and D. Kaluge, "Analisis Faktor-Faktor yang Mempengaruhi Kemiskinan di Indonesia Selama Lima Tahun Terakhir (Studi Kasus pada 33 Provinsi)," Jurnal Ilmiah Bisnis dan Ekonomi Asia, vol. 11, no. 2, pp. 27-31, 2017.

[5] Y. C. Pratama, "Analisis Faktor-Faktor yang Mempengaruhi Kemiskinan di Indonesia," Esensi: Jurnal Bisnis dan Manajemen, vol. 4, no. 2, Sep. 2014.

[6] A. N. Ulfah and S. 'Uyun, "Analisis Kinerja Algoritma Fuzzy C-Means dan K -Means pada Data Kemiskinan,” JATISI (Jurnal Teknik Informatika dan Sistem Informasi), vol. 1, no. 2, pp. 139-148, 2015 .

[7] A. Mulyani, “Analisis Neural Network Struktur Backpropagation sebagai Metode Peramalan pada Perhitungan Tingkat Kemiskian di Indonesia," Techno Nusa Mandiri, vol. 13, no. 1, pp. 9-15, 2016.

[8] S. Mamase and R. S. Sinukun, "Prediksi Tingkat Kemiskinan Provinsi Gorontalo dengan Metode GRNN," in Seminar Nasional Humaniora \& Aplikasi Teknologi Informasi 2018, 2018, pp. 29-32.

[9] L. M. Patnaik and K. Rajan, "Target Detection Through Image Processing and Resilient Propagation Algorithms," Neurocomputing, vol. 35, no. 1-4, pp. 123-135, Nov. 2000.

[10] A. K. Santra, N. Chakraborty, and S. Sen, "Prediction of Heat Transfer Due to Presence of Copperwater Nanofluid Using Resilient-propagation Neural Network," International Journal of Thermal Sciences, vol. 48, no. 7, pp. 1311-1318, Jul. 2009.

[11] L. M. Saini, "Peak Load Forecasting Using Bayesian Regularization, Resilient and Adaptive Backpropagation Learning Based Artificial Neural Networks," Electric Power Systems Research, vol. 78, no. 7, pp. 1302-1310, Jul. 2008.

[12] S. Kumar and B. K. Tripathi, "High-Dimensional Information Processing Through Resilient Propagation in Quaternionic Domain,” Journal of Industrial Information Integration, vol. 11, pp. 4149, Sep. 2018.

[13] R. P. Satya Hermanto, Suharjito, Diana, and A. Nugroho, "Waiting-Time Estimation in Bank Customer Queues using RPROP Neural Networks," Procedia Computer Science, vol. 135, pp. 35-42, 2018.

[14] R. Y. Fa'rifah and Z. Busrah, "Backpropagation Neural Network untuk Optimasi Akurasi pada Prediksi Financial Distress Perusahaan,” Jurnal INSTEK (Informatika Sains dan Teknologi), vol. 2, no. 2, pp. 101-110, 2017.

[15] W. Watsuntorn, R. Khanongnuch, W. Chulalaksananukul, E. R. Rene, and P. N. L. Lens, "Resilient Performance of An Anoxic Biotrickling Filter for Hydrogen Sulphide Removal From A Biogas Mimic: Steady, Transient State and Neural Network Evaluation," Journal of Cleaner Production, vol. 249, p. 119351, Mar. 2020. 
[16] A. Poole and A. Kotsialos, "Second Order Macroscopic Traffic Flow Model Validation Using Automatic Differentiation with Resilient Backpropagation and Particle Swarm Optimisation Algorithms," Transportation Research Part C: Emerging Technologies, vol. 71, pp. 356-381, Oct. 2016.

[17] M. Shiblee, B. Chandra, and P. K. Kalra, "Learning of Geometric Mean Neuron Model Using Resilient Propagation Algorithm,” Expert Systems with Applications, vol. 37, no. 12, pp. 7449-7455, Dec. 2010. 
Matrik : Jurnal Manajemen, Teknik Informatika dan Rekayasa Komputer, Vol. 20, No. 1, November 2020: 11 18 